\title{
Clinically significant subjective features of highly qualified athletes with different types of cardiac rhythm regulation
}

\author{
O. V. Guzii (D)*1,A,B,C,D,F, A. V. Mahlovanyi (D2,A,E,F, V. M. Trach (D1,A,E,F \\ ${ }^{1}$ Lviv State University of Physical Culture named after Ivan Boberskyj, Ukraine, ${ }^{2}$ Danylo Halytsky Lviv National Medical University, Ukraine
}

A - research concept and design; B - collection and/or assembly of data; C - data analysis and interpretation; D - writing the article;

$\mathrm{E}$ - critical revision of the article; $\mathrm{F}$ - final approval of the article

The aim of the study is to identify the characteristic subjective features of highly qualified athletes with different types of cardiac rhythm regulation.

Materials and methods. 202 highly qualified male athletes aged $22.6 \pm 2.8$ years and engaged in acyclic sports were examined. According to the designed survey protocol, all athletes were interviewed using a specifically designed questionnaire, which included 4 questions pools, each of them characterized certain components of athletes' subjective assessment of their condition and attitude to it during the previous week, as well as studies using spiroarteriocardiorhythmography (SACR).

Results. The SACR study allowed to divide athletes, taking into account heart rate variability (HRV) parameters, into 4 groups according to the types of their cardiac rhythm regulation. Subjective signs that might have clinical significance in the development of cardiovascular overexertion were uncomfortable sensations in the heart, feeling of interruption in the heart work, perspiration at rest, headache after sleep, perspiration at low loads, feeling of fatigue after sleep and night perspiration. Uncomfortable sensations in the heart occurred frequently in $1 \%$ of cases and periodically in $15.3 \%$ of cases, and feeling of interruption in the heart work occurred frequently in $0.5 \%$ of cases and periodically in $14.9 \%$ of cases. These indications were typical of people with cardiac rhythm regulations type I and II. In type III the least number of clinically significant features was noted. In type IV the number of significant features was less than in types I and II; however, this is nonsignificant. Probable differences in the features of perspiration at rest were noticed in athletes with type IV in comparison with type III.

Conclusions. Subjective indications can be employed to verify the regulatory features of the cardiovascular system, which are associated with the centralization of effects. Questionnaires can be useful in differentiating states of overexertion according to parasympathetic type and a state of high training level in type IV cardiac rhythm regulation.

Key words: data collection, medical history taking, heart rate, athlete.

Current issues in pharmacy and medicine: science and practice 2021; 14 (1), C. 84-92

Клінічно значущі суб’єктивні ознаки висококваліфікованих спортсменів із різними типами регуляції серцевого ритму О. В. Гузій, А. В. Магльований, В. М. Трач

Мета роботи - визначити характерні суб'єктивні ознаки висококваліфікованих спортсменів із різними типами регуляції серцевого ритму.

Матеріали та методи. Обстежили 202 висококваліфікованих спортсменів чоловічої статі віком 22,6 $\pm 2,8$ року, які займаються ациклічними видами спорту. Усіх спортсменів згідно з протоколом обстеження опитали, використовуючи анкету, яку розробили. Опитувальник складається 34 блоків запитань, кожен із них характеризував певні складові суб'єктивного оцінювання власного стану та ставлення до нього протягом попереднього тижня. Крім того, всім обстеженим виконали спіроартеріокардіоритмографію (САКР).

Результати. САКР дослідження дало можливість диференціювати спортсменів з урахуванням параметрів варіабельності серцевого ритму (ВСР) на 4 групи за типами регуляції серцевого ритму. Суб'єктивні ознаки, які можуть мати клінічне значення у разі розвитку перенапружень серцево-судинної системи: неприємні відчуття в ділянці серця, відчуття перебоїв у роботі серця, пітливість у стані спокою, головний біль після сну, пітливість під час незначних навантажень, наявність відчуття втоми після сну та пітливість у нічний період. Часті неприємні відчуття в ділянці серця відзначили 1 \% респондентів, періодичні - 15,3 \%; часте відчуття перебоїв у роботі серця - 0,5 \% опитаних, періодичне - 14,9\%. Ці ознаки характерні для I та II типів регуляції серцевого ритму. При III типі виявили найменшу кількість клінічно значущих ознак. При IV типі кількість значущих ознак була меншою, ніж при I та II типах, але невірогідно. Вірогідними у спортсменів із IV типом, порівнюючи зі спортсменами з III типом, були відмінності за ознакою пітливості у спокої.

ARTICLE

INFO

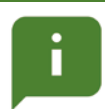

http:l/pharmed.

zsmu.edu.ualarticle/

view/226852
UDC 796.015.6:612.172

DOI: $10.14739 / 2409-2932.2021 .1 .226852$

Current issues in pharmacy and medicine: science and practice $2021 ; 14$ (1), 84-92

Key words: data collection, medical history taking, heart rate, athlete.

*E-mail: o.guzij@gmail.com

Received: 12.10.2020 // Revised: 19.11.2020 // Accepted: 27.11.2020 
Висновки. За суб'єктивними ознаками можна визначити регуляторні особливості серцево-судинної системи, що пов'язані з централізацією впливів. Анкетування може бути корисним для диференціації станів перенапруження за парасимпатичним типом та станом високої тренованості при IV типі регуляції серцевого ритму.

Ключові слова: збір даних, збір анамнезу, серцевий ритм, спортсмени.

Актуальні питання фрармацевтичної і медичної науки та практики. 2021. Т. 14, № 1(35). 84-92

Клинически значимые субъективные признаки высококвалифицированных спортсменов с различными типами регуляции сердечного ритма

\section{О. В. Гузий, А. В. Маглёваный, В. М. Трач}

Цель работы - определить характерные субъективные признаки высококвалифицированных спортсменов с различными типами регуляции сердечного ритма.

Материалы и методы. Обследовали 202 высококвалифицированных спортсменов мужского пола в возрасте 22,6 \pm 2,8 года, которые занимаются ациклическими видами спорта. Все спортсмены согласно протоколу обследования прошли опрос с использованием разработанной нами анкеты, которая была сформирована из 4 блоков вопросов, каждый из них характеризовал определенные составляющие субъективной оценки собственного состояния и отношение к нему в течение предыдущей недели. Кроме того, всем обследованным проведена спироартериокардиоритмография (САКР).

Результаты. САКР-исследование позволило дифференцировать спортсменов с учетом параметров вариабельности сердечного ритма (ВСР) на 4 группы по типам регуляции сердечного ритма. Субъективные признаки, которые могут иметь клиническое значение при развитии перенапряжений сердечно-сосудистой системы: неприятные ощущения в области сердца, ощущение перебоев в работе сердца, потливость в состоянии покоя, головная боль после сна, потливость при незначительных нагрузках, наличие ощущения усталости после сна и потливость в ночное время. Частые неприятные ощущения в области сердца отметили $1 \%$ респондентов, периодически - 15,3\%; частое ощущение перебоев в работе сердца - 0,5 \% обследованных, периодически - 14,9 \%. Эти признаки характерны для I и II типов регуляции сердечного ритма. При III типе отмечено наименьшее количество клинически значимых признаков. При IV типе количество значимых признаков было меньше, чем при I и II типах, но недостоверно. Достоверными у спортсменов с IV типом в сравнении со спортсменами с III типом были отличия по признаку потливости в покое.

Выводы. По субъективным признакам можно определить регуляторные особенности сердечно-сосудистой системы, связанные с централизацией влияний. Анкетирование может быть полезным при дифференциации состояний перенапряжения по парасимпатическому типу и состоянием высокой тренированности при IV типе регуляции сердечного ритма.

Ключевые слова: сбор данных, сбор анамнеза, сердечный ритм, спортсмены.

Актуальные вопросы фрармацевтической и медицинской науки и практики. 2021. Т. 14, № 1(35). С. 84-92

The problem of routine monitoring of athletes is related to the individual assessment of the effect of training and competitive loads, as well as recovery after them [1-4]. It is important to consider not only objective but also subjective features that would allow to standardize a comprehensive assessment of athletes' condition [1-3,5,6].

At the level of determining the physiological parameters that reflect the body's response to exercise, according to changes in energy supply [7-9], in cardiovascular [1-14], respiratory $[15,16]$, sensorimotor systems [17-19], in metabolic processes [20-22], accompanied by changes in the immune response [20], endocrine regulation [23], methods of determining the subjective assessment of load perception, as well as psychophysical changes in the athlete's body are essential [24-26]. Some authors emphasize certain advantages of their use in the training process [27].

In recent years, a significant number of questionnaires and their modifications, providing a meticulous assessment of the effect of sports, as well as external factors on the recovery of an athlete, have appeared $[6,28]$. Their use in determining or regulating non-functional overstrain has been tested [29-33].

Within microcycles, it is proposed to use the Acute Recovery and Stress Quick (ARSQ), which has 8 scales for assessing physical, mental, emotional and general recovery, as well as stress [29,30]. A short version (SRSS) is also used; it is suitable for multiple measurements at short intervals, for example, in experimental conditions to evaluate recovery strategies [31], as well as in long-term monitoring [32]. The developers emphasize that the effectiveness of questionnaires depends on the responsibility and diligence of athletes, so it is important to ensure the confidentiality, proper use and estimation of data provided by athletes [34,35]. When examining a large number of athletes, the survey allows to quickly and economically collect data on their condition, especially after intense training or competition. This helps develop and adjust individual training schemes, taking into account the characteristics of the sport, as well as the psychophysiological state of athletes after competitions or training. At the same time, it is emphasized that survey data will be the most informative in combination with possible physiological research methods [6,36,37].

The method of spiroarteriocardiorhythmography (SACR) [38] has been tested by us in numerous field studies of athletes [39-42]. This allowed us to use the mentioned method in a comprehensive monitoring survey of athletes during the pre-competition period of the annual training cycle in combination with questionnaires.

\section{Aim}

The purpose of the work is to identify typical subjective characteristics of highly qualified athletes with different types of cardiac rhythm regulation. 
Table 1. Criteria for determining the types of cardiac rhythm regulation according to N. I. Shlyk

\begin{tabular}{|c|c|c|c|}
\hline \multirow{2}{*}{ Type of regulation } & \multirow{2}{*}{ Group } & \multicolumn{2}{|l|}{ Criteria } \\
\hline & & SI, conventional units & VLF, Ms $^{2}$ \\
\hline \multirow{2}{*}{ Predominance of central regulation } & 1 & $>100$ & $>240$ \\
\hline & $\|$ & $>100$ & $<240$ \\
\hline \multirow{2}{*}{ Predominance of autonomous regulation } & III & $25-100$ & $>240$ \\
\hline & IV & $<25$ & VLF $>500, T P>8000-10000$ \\
\hline
\end{tabular}

\section{Materials and methods}

Using spiroarteriocardiorhythmography (SACR), 202 highly qualified male athletes aged $22.6 \pm 2.8$ years and engaged in acyclic sports, namely various martial arts (karate, taekwondo, kickboxing, boxing, judo, sambo, wrestling) and sport games (water polo, football), were examined. Their experience of sports training was $10.3 \pm 3.1$ years. All studies were conducted in the pre-competition period. The SACR study was performed in the morning, on an empty stomach, in a sitting position. Registration lasted for 2 minutes. Before SACR study, questionnaires, morphometric examinations, and standard methods of measuring arterial systolic (SPB) and diastolic pressure (DPB) were performed [43].

According to the developed survey protocol, all athletes were interviewed using a specifically designed questionnaire, which included 4 questions pools. Each of them characterized certain components of athletes' subjective estimation of their own condition and attitude to it during the previous week. Each question was evaluated on a three-point scale, which provided an opportunity to characterize various features as non-occurring (scoring "0" points), occurring periodically (scoring "1" point) or often (scoring "2" points).

The first pool included questions that characterized the subjective signs of the general condition of an athlete at the time of the examination: psycho-emotional state, appetite, body weight dynamics, the presence of cardiovascular system complaints, headache, sweating and more. The second pool included questions related to characteristics and sensations during and after sleep, such as falling asleep, dreaming, waking up, the presence of fatigue after waking up, sweating in sleep, and so on. The third pool included questions related to sensations and manifestations during training loads. The fourth pool of questions was formed to understand the attitude of athletes to the recovery procedures used in the training process. However, the analysis of the results of the latter was not conducted in this study.

The type of autonomous regulation of the cardiac rhythm of athletes was determined according to the approach proposed by N. I. Shlyck $[44,45]$, which grounds the classification of $\mathrm{HRV}$ on the data with the definition of TP $\left(\mathrm{ms}^{2}\right)$, SI (c. u.) and $\operatorname{VLF}\left(\mathrm{ms}^{2}\right)$. There are 4 Types of autonomic regulation of cardiac rhythm: Type I shows moderate stress, Type II shows a decrease in the functional state of regulatory systems, the development of fatigue, Type III shows the optimal state of regulation, Type IV shows overstrain of autonomic regulation, or high fitness.
The principles of types classification, taking into account the above mentioned criteria, are presented in Table 1.

Statistical analysis of the physiological study results was performed to determine the differences between the groups using Mann-Whitney test. Subjective parameters were analyzed using the percentile method.

\section{Results}

According to the survey of athletes, the information on the peculiarities of classes and recreation organization in the pre-competition period was provided. It was related to the number of trainings (per week) $-6.0 \pm 2.2$, the average duration of one training (min.) $-121.0 \pm 24.0$, the average duration of training (min. per week) $-726 \pm 314$ and the average duration of sleep (hours) $-7.8 \pm 1.1$.

Analyzing the survey data in the whole group of athletes (Table 2), we will focus on the questions of each pool. According to the answers to the question about the general condition, it should be noted that in the vast majority of athletes, negative symptoms associated with discomfort in the heart, a feeling of heart failure, sweating at rest are not frequent, but occur periodically in $13.9-15.8 \%$ of cases. Very rarely (up to $5 \%$ ) athletes report loss of appetite, variability in body weight, headache, and persistent reluctance to train. Feelings of lethargy, apathy, lack of vigor are within the expected range (5.0-5.9\%), while $8.9 \%$ of athletes report frequent irritability and $12.9 \%$ of them report increased excitability. Periodically, the above symptoms are observed between $21.8 \%$ (for loss of appetite) and $57.9 \%$ (for a feeling of increased excitability). The exception is the question on the feeling of reduced efficiency, which appears periodically in $72.8 \%$ of cases. And only $11.4 \%$ of athletes report it as frequent.

Analyzing the answers to the questions pool "Sleep", it should be noted that frequent sleep disorders in the studied group of athletes are quite rare (up to $5 \%$ ). However, a number of athletes (7.9\%) often report the presence of shallow sleep, and a certain number $(5 \%)$ often have a feeling of fatigue after sleep. This sign is most often defined by athletes as recurrent ( $48.5 \%$ of cases). Slightly less often (35.6\% of cases), athletes notice periodically occurring poor sleep. All other subjective signs of recurrent sleep disorders occur in $10.0 \%$ to $25.0 \%$ of cases, which can be considered as expected. Among the characteristics of this question pool, there are the answers about poor sleep, the presence of a feeling of fatigue after sleep, as well as shallow sleep. 
Table 2. The distribution of answers to the questionnaire by pools and their average scores in the studied group of athletes, $\mathrm{n}(\%)$

\begin{tabular}{|c|c|c|c|}
\hline Question pools & $\begin{array}{l}\text { no } \\
(0)\end{array}$ & $\begin{array}{l}\text { periodically } \\
\text { (1) }\end{array}$ & $\begin{array}{l}\text { often } \\
(2)\end{array}$ \\
\hline \multicolumn{4}{|c|}{ Question pool 1: "General condition" } \\
\hline Impaired appetite & $151(74.8)$ & $44(21.8)$ & $7(3.5)$ \\
\hline Weight loss & $116(57.4)$ & $81(40.1)$ & $5(2.5)$ \\
\hline $\begin{array}{l}\text { Headache regardless of external } \\
\text { conditions }\end{array}$ & $155(76.7)$ & $44(21.8)$ & $3(1.5)$ \\
\hline Unpleasant sensations in the heart & $169(83.7)$ & $31(15.3)$ & $2(1.0)$ \\
\hline Feeling of heart failure & $171(84.7)$ & $30(14.9)$ & $1(0.5)$ \\
\hline Feeling of reduced efficiency & $32(15.8)$ & $147(72.8)$ & $23(11.4)$ \\
\hline Feeling vigor & $115(56.9)$ & $75(37.1)$ & $12(5.9)$ \\
\hline Feeling of increased excitability & $59(29.2)$ & $117(57.9)$ & $26(12.9)$ \\
\hline Irritability & $78(38.6)$ & $106(52.5)$ & $18(8.9)$ \\
\hline Feelings of lethargy & $80(39.6)$ & $111(55.0)$ & $11(5.4)$ \\
\hline Apathy, mood swings & $120(59.4)$ & $69(34.2)$ & $13(6.4)$ \\
\hline Persistent reluctance to train & $146(72.3)$ & $47(23.3)$ & $9(4.5)$ \\
\hline Sweating at rest & $163(80.7)$ & $30(14.9)$ & $9(4.5)$ \\
\hline \multicolumn{4}{|l|}{ Question pool 2: “Sleep” } \\
\hline Perspiration at night & $160(79.2)$ & $39(19.3)$ & $3(1.5)$ \\
\hline Poor sleep & $124(61.4)$ & $72(35.6)$ & $6(3.0)$ \\
\hline Shallow sleep & $149(73.8)$ & $37(18.3)$ & $16(7.9)$ \\
\hline Terrible dreams / Nightmares & $174(86.1)$ & $22(10.9)$ & $6(3.0)$ \\
\hline Frequent waking up & $146(72.3)$ & $50(24.8)$ & $6(3.0)$ \\
\hline Feeling of fatigue after sleep & $94(46.5)$ & $98(48.5)$ & $10(5.0)$ \\
\hline Headache after sleep & $179(88.6)$ & $18(8.9)$ & $5(2.5)$ \\
\hline \multicolumn{4}{|l|}{ Question pool 3: "Training" } \\
\hline Intense sweating during exercise & 64 (31.7) & $82(40.6)$ & $56(27.7)$ \\
\hline Sweating at low loads & $68(33.7)$ & $103(51.0)$ & $31(15.3)$ \\
\hline High efficiency & $134(66.3)$ & $57(28.2)$ & $11(5.4)$ \\
\hline $\begin{array}{l}\text { Feeling of heaviness in working } \\
\text { muscles }\end{array}$ & $52(26.0)$ & $130(65.0)$ & $18(9.0)$ \\
\hline Lack of feeling of ease at walking & $84(41.6)$ & $76(37.6)$ & $42(20.8)$ \\
\hline $\begin{array}{l}\text { Feeling of fatigue of the day after } \\
\text { training }\end{array}$ & $72(35.6)$ & $116(57.4)$ & $14(6.9)$ \\
\hline Slow entry into work & $118(58.4)$ & $64(31.7)$ & $20(9.9)$ \\
\hline Feeling of heaviness during training & $62(30.7)$ & $126(62.4)$ & $14(6.9)$ \\
\hline $\begin{array}{l}\text { Fear of performing complex } \\
\text { exercises }\end{array}$ & $150(74.3)$ & 37 (18.3) & $15(7.4)$ \\
\hline
\end{tabular}

Most of the subjective feelings of athletes are related to training, which is quite expected. Among the signs that may have a functional burden, there are intense perspiration during exercise $(27.7 \%$ - frequent, $40.6 \%$ - periodic $)$, sweating at low loads ( $15.3 \%$ - frequent, $51.0 \%$ - periodic). Other signs are usual for fitness trainings; however, they can have diagnostic value when the frequency of their occurrence is increased: feeling of heaviness in working muscles $(9.0 \%$ of cases), lack of feeling of ease at walking (20.8\% of cases), feeling of fatigue for the rest of the day after training $(6.9 \%$ of cases), as well as a feeling of heaviness during training (6.9\% of cases).

Certainly, an increase in the frequency of the above mentioned symptoms may indicate the development of overstrain of the cardiovascular system and musculoskeletal system, as well as overtraining of athletes.

Examination of athletes using SACR allowed to differentiate them (taking into account the parameters of HRV) into 4 groups according to the types of cardiac rhythm regulation. Table 3 shows their distribution and average data that indicate their clear verification.

Characterizing athletes with different types of regulation, attention should be paid to morphometric and routine integrated indicators (Table 4), which differ significantly in Type IV. They show significantly lower body mass index (BMI, $\mathrm{kg} \cdot \mathrm{m}^{-2}$ ), chest circumference $(\mathrm{cm})$ and higher vital index (VI, $\mathrm{kg} \cdot \mathrm{ml}^{-1}$ ), compared with other athletes. A similar difference is shown by the integral parameters of autonomic tone (vegetative index), economization of the cardiovascular system (Robinson index) and physical performance (according to the level of functional state (LFS) by Pirogova). Athletes of Type III (optimal) regulation considerably differ from athletes belonging to Type I and II according to the mentioned integral parameters. However, they do not differ significantly in morphometric parameters. At the same time, morphometric and standard integrated indicators of athletes with Type I and II regulation are generally similar.

An important component of determining the functional overstrain is the characterization of the subjective characteristics of the athlete, which can be combined with the development of such states. A significant number of publications in this regard show a fairly high efficiency in assessing the current state of the athlete [46].

Taking into account the aim of the work, related to the assessment of subjective symptoms in athletes with different types of cardiac rhythm regulation, we analyzed the answers to questions that may have clinical significance (Table 5).

The presented data demonstrate that each of the types of regulatory cardiac rhythm is accompanied by a number of subjective features that may have clinical significance. The least number of such manifestations are observed in Type III, the most - in Type II. Comparing the data of registration of subjective traits in athletes with different types of regulation, it should be noted that this study surveyed athletes in the pre-competition period of the training process, which did not allow us to track the dynamics of changes in cardiac rhythm regulation in individual athletes. However, the simultaneity and combination of testing allowed to more fully characterize the conditions that develop in athletes under the influence of physical activity.

First of all, the subjective characteristics of athletes, which are rare in the studied group, deserve attention. Unpleasant sensations in the heart and sensations of interruptions are quite 
Table 3. Average values of HRV indicators, which were the basis for the differentiation of athletes by types of cardiac rhythm regulation

\begin{tabular}{|l|l|l|l|l|}
\hline Type of regulation & $\mathbf{n}$ & TP, ms $^{2}$ & VLF, $\mathrm{ms}^{2}$ & SI, c.u. \\
\hline I type & 42 & $2490(1632 ; 3844)$ & $610(331 ; 1406)$ & $143.4(122.9 ; 214.5)$ \\
\hline II type & 28 & $1475(1163 ; 2314)$ & $161(144 ; 188)$ & $222.1(150.8 ; 282.8)$ \\
\hline III type & 88 & $5686(4186 ; 12679)$ & $770(471 ; 1600)$ & $57.7(38.5 ; 70.3)$ \\
\hline IV type & 44 & $18540(12645 ; 26392)$ & $1490(992 ; 2061)$ & $17.4(13.3 ; 19.9)$ \\
\hline
\end{tabular}

Table 4. Comparative characteristics of morphometric and routine parameters of athletes with different types of cardiac rhythm regulation, $\mathrm{M}(\mathrm{Q} 1$; Q3)

\begin{tabular}{|c|c|c|c|c|}
\hline Indicators & I type & II type & III type & IV type \\
\hline Body mass, kg & $75.0(62.0 ; 84.0)$ & $75.0(70.0 ; 87.0)$ & $73.0(64.0 ; 79.5)$ & $70.7(58.5 ; 82.5)$ \\
\hline Body length, cm & $181(169 ; 188)$ & $181(172 ; 190)$ & $175(170 ; 186)$ & $175(170 ; 185)$ \\
\hline $\mathrm{BMI}, \mathrm{kg} \cdot \mathrm{m}^{-2}$ & $23.1(21.1 ; 25.2)$ & $22.2(21.4 ; 26.7)$ & $22.5(20.9 ; 24.7)$ & $20.9(20.0 ; 26.2)$ \\
\hline $\mathrm{HR}, \mathrm{m}^{-1}$ & $70.3(62.9 ; 74.4)$ & $66.2(62.5 ; 71.8)$ & $59.2(54.0 ; 65.4)$ & $54.1(49.9 ; 61.2)$ \\
\hline SBP, mmHg & $120(110 ; 130)$ & $120(116 ; 130)$ & $120(110 ; 130)$ & $110(106 ; 120)$ \\
\hline $\mathrm{DBP}, \mathrm{mmHg}$ & $76(70 ; 80)$ & $76(70 ; 80)$ & $72(64 ; 80)$ & $70(68 ; 80)$ \\
\hline PBP, mmHg & $50(40 ; 54)$ & $54(40 ; 60)$ & $42(40 ; 50)$ & $40(35 ; 47)$ \\
\hline Vegetative index & $-0.08(-0.19 ; 0.06)$ & $-0.11(-0.22 ; 0.01)$ & $-0.23(-0.33 ;-0.07)$ & $-0.34(-0.57 ;-0.18)$ \\
\hline Robinson index & $82.4(69.6 ; 94.8)$ & $79.4(77.4 ; 94.1)$ & $72.0(62.4 ; 79.4)$ & $61.5(56.5 ; 71.0)$ \\
\hline Baevsky’s AP & $2.26(1.88 ; 2.40)$ & $2.21(2.06 ; 2.27)$ & $2.01(1.82 ; 2.19)$ & $1.89(1.72 ; 2.02)$ \\
\hline LFS by Pirogova & $0.67(0.55 ; 0.78)$ & $0.69(0.63 ; 0.70)$ & $0.75(0.68 ; 0.83)$ & $0.81(0.75 ; 0.90)$ \\
\hline
\end{tabular}

Table 5. The comparison of distributions of clinically significant subjective features of athletes with different types of regulatory support of the cardiovascular system

\begin{tabular}{|c|c|c|c|c|c|c|c|c|c|c|c|c|c|}
\hline & & \multicolumn{3}{|l|}{ I type } & \multicolumn{3}{|l|}{ II type } & \multicolumn{3}{|l|}{ III type } & \multicolumn{3}{|l|}{ IV type } \\
\hline & & ㅇ & 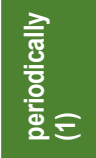 & 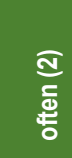 & 으 & 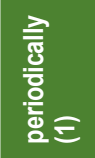 & 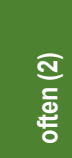 & 으 & 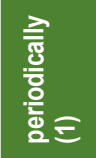 & 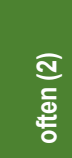 & 으 & 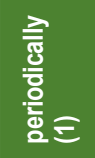 & 홍 \\
\hline \multirow{2}{*}{$\begin{array}{l}\text { Uncomfortable sensations } \\
\text { in the heart }\end{array}$} & $n$ & 31 & 10 & 1 & 17 & 10 & 1 & 82 & 6 & 0 & 39 & 5 & 0 \\
\hline & $\%$ & 73.8 & 23.8 & 2.4 & 60.7 & 35.7 & 3.6 & 93.2 & 6.8 & 0.0 & 88.6 & 11.4 & 0.0 \\
\hline \multirow{2}{*}{$\begin{array}{l}\text { Feeling of interruption in the } \\
\text { heart work }\end{array}$} & $n$ & 31 & 11 & 0 & 17 & 11 & 0 & 80 & 7 & 1 & 43 & 1 & 0 \\
\hline & $\%$ & 73.8 & 26.2 & 0.0 & 60.7 & 39.3 & 0.0 & 90.9 & 8.0 & 1.1 & 97.7 & 2.3 & 0.0 \\
\hline \multirow{2}{*}{ Sweating at rest } & $\mathrm{n}$ & 31 & 8 & 3 & 19 & 6 & 3 & 81 & 7 & 0 & 32 & 9 & 3 \\
\hline & $\%$ & 73.8 & 19.0 & 7.1 & 67.9 & 21.4 & 10.7 & 92.0 & 8.0 & 0.0 & 72.7 & 20.5 & 6.8 \\
\hline \multirow{2}{*}{ Sweating at night } & $\mathrm{n}$ & 30 & 11 & 1 & 21 & 5 & 2 & 75 & 13 & 0 & 34 & 10 & 0 \\
\hline & $\%$ & 71.4 & 26.2 & 2.4 & 75.0 & 17.9 & 7.1 & 85.2 & 14.8 & 0.0 & 77.3 & 22.7 & 0.0 \\
\hline \multirow{2}{*}{ The feeling of fatigue after sleep } & $n$ & 21 & 18 & 3 & 11 & 14 & 3 & 40 & 45 & 3 & 22 & 21 & 1 \\
\hline & $\%$ & 50.0 & 42.9 & 7.1 & 39.3 & 50.0 & 10.7 & 45.5 & 51.1 & 3.4 & 50.0 & 47.7 & 2.3 \\
\hline \multirow{2}{*}{ Headache after sleep } & $\mathrm{n}$ & 39 & 2 & 1 & 21 & 6 & 1 & 76 & 9 & 3 & 43 & 1 & 0 \\
\hline & $\%$ & 92.9 & 4.8 & 2.4 & 75.0 & 21.4 & 3.6 & 86.4 & 10.2 & 3.4 & 97.7 & 2.3 & 0.0 \\
\hline \multirow{2}{*}{ Sweating at low loads } & $n$ & 2 & 26 & 14 & 2 & 19 & 7 & 45 & 38 & 5 & 19 & 20 & 5 \\
\hline & $\%$ & 4.8 & 61.9 & 33.3 & 7.1 & 67.9 & 25.0 & 51.1 & 43.2 & 5.7 & 43.2 & 45.5 & 11.4 \\
\hline
\end{tabular}


typical of the Types of regulation I and II, which are observed in the centralization of cardiac rhythm regulation. In Type I, they occur periodically and often in every fourth athlete (23.8 \% and $2.4 \%$, respectively). They are slightly more often in Type II: in $35.7 \%$ and $3.6 \%$ of cases, respectively. However, they are also periodically registered in Types III and IV: in $6.8 \%$ and $11.4 \%$ of cases. On the other hand, they often occur in only 2 athletes ( $1 \%$ ) of the entire group studied.

The subjective sign associated with the feeling of interruptions in the heart is mainly found in athletes of Type I and II regulation (periodically in $26.2 \%$ and $39.3 \%$ ). In Types III and IV it is rare $(9.1 \%$ and $2.3 \%)$. However, it was detected as frequent in one of the athletes belonging to Type III. It is quite informative that despite a significant sinus arrhythmia, no sensations in work of interruption were fixed among athletes of Type IV.

Other features of the options for centralization (Types I and II) and autonomy (Types III and IV) of cardiovascular regulation are not significantly related. However, with optimal (Type III) regulatory support, sweating at rest is the least often $(8 \%)$. In other types, it occurs from $26.1 \%$ to $32.1 \%$ of cases. At the same time, with excessive influence of the sympathetic division (Type II) it is often in $10.7 \%$ of cases, and with excessive vagotonic impact (Type IV) - in $6.8 \%$, which does not clearly differentiate these groups. Sweating at night is the least often, in $14.8 \%$ of cases, periodically occurs in athletes of Type III. In others it ranges from $22.7 \%$ to $28.6 \%$, which also does not allow to characterize as specific for any of the Types.

Athletes of Type II complain of sleep fatigue more often $-50.0 \%$ periodically and $10.7 \%$ often. However, in other Types it occurs in $50.0 \%$ to $54.4 \%$ of athletes and is less often - from $2.3 \%$ in type IV to $7.1 \%$ in Type I. The symptom associated with post-sleep headache is in some way different. Most often (in every fourth athlete) it is observed in Type II. It is rarely fixed $(2.3 \%)$ in Type IV. On the other hand, it occurs in every seventh athlete with optimal (Type III) regulation. A sign of sweating at low loads, which is registered in the vast majority of athletes $(95.2 \%$ and $92.9 \%$ of cases, respectively) was quite characteristic for Types I and II. However, with the autonomy of regulation (Types III and IV), it is also often and is observed in half (48.9\%) and more $(56.9 \%)$ of athletes.

\section{Discussion}

The analysis of subjective signs that characterize the general condition, sleep and feelings during training revealed that most changes in athlete's feelings determine the nature of the adaptive reactions of the body that occur in the training process. Symptoms that are rare and may be of clinical significance in the development of cardiovascular overstrain have been identified. These included: uncomfortable sensations in the heart, a feeling of heart failure, sweating at rest, headache after sleep, sweating at low loads, the presence of fatigue after sleep, night sweats.

They are quite rare in athletes. Exceptions are the signs that characterize the presence of fatigue after sleep and the activity of the activation of autonomous mechanisms of thermoregulation, as well as autonomic dysregulation (according to sweating).

Discomfort in the heart is a non-specific symptom that can occur in various conditions related to heart function, such as myocardial ischemia with excessive stretching of the heart chambers, which can occur with increasing end-diastolic size, a number of inflammatory diseases of different layers of the heart, aortic lesions, etc. [47-50]. These sensations can also have reflexive nature and be associated with the condition of the spine or excessive activation of the branches of the sympathetic ANS [51-53]. Despite the fact that this feature is quite rare in the surveyed group of athletes (often in $1 \%$ of cases and periodically in $15.3 \%$ of cases), it deserved a meticulous analysis, which showed its significant predominance in the centralization of regulatory effects on heart rate. However, in some cases, it can occur with the predominance of autonomous influences.

Feeling of heart failure is also a non-specific symptom; however, it has a clear connection with heart function, namely arrhythmia. This feature in the studied group of athletes is also quite rare (often in $0.5 \%$ of cases and periodically in $14.9 \%$ of cases). Its presence, as a rule, may indicate the appearance of an extrasystolic form of arrhythmia, and, most likely, ventricular [47,49]. However, it can be variably present as sinus node weakness, when one or more heart contractions may occur [54]. Other forms of arrhythmic disorders usually have a more stable course. The same forms such as sinus arrhythmia, which is characteristic of athletes, or atrial extrasystole, usually do not cause subjective sensations. Thus, in athletes belonging to Type IV, who have very pronounced sinus arrhythmia, the feeling of interruption in work was noted in only $2.3 \%$ and only periodically.

Sweating at rest in the absence of other symptoms is a sign of adjustment of thermoregulatory processes and stress of the autonomic nervous system in ensuring metabolism. In the whole group of surveyed athletes, this symptom is often present in $4.5 \%$ of cases, and periodically - in $14.9 \%$ of cases. Taking into account the type of cardiac rhythm regulation, it was the least often (in $8 \%$ of cases) in optimal (Type III), most often in $32.1 \%$ and $27.3 \%$ of cases in autonomic dysregulation of the sympathetic and parasympathetic type, respectively. Quite rarely it occurred in Type I (26.1\% of cases).

Headache after sleep is a very important sign of impaired cerebral blood flow during sleep and failure to restore neck muscle tone, which also has autonomous determinants [54]. In general, among athletes, it occurs frequently and periodically in $11.4 \%$ of cases. However, it may also indicate deterioration in the regulation of systemic circulation and be accompanied by an increase (more often) or a decrease (less often) in blood pressure. Most often, it shows the predominance of sympathicotonic effects in every fourth athlete. Rarely $(2.3 \%)$ it is observed with a predominance of vagotonic effects.

A rather important sign of the presence of autonomic dysregulation is night sweats, when a number of anabolic 
processes, aimed at restoring the structures and functions of the body after daytime stress of catabolic mechanisms associated with life, take place [22]. Usually, sweating during sleep is accompanied by lytic processes of thermoregulation, which implement the return of accumulated heat, as in case of a number of inflammatory diseases [23]. In athletes, sweating during sleep can characterize the processes of hypothalamic-pituitary and autonomic dysfunction and indicate the tension of adaptive mechanisms in the body [10]. In our study, night sweats occur frequently and periodically in one of five athletes (only $20.8 \%$ of cases).

Signs of fatigue after sleep and sweating at low physical loads have a certain pre-nosological significance. These symptoms are quite common: in $53.5 \%$ and $66.3 \%$, respectively. The presence of fatigue after sleep is a characteristic sign of insufficient recovery, but it can occur with excessive stress of the previous day, when the body has little time to fully recover, and the presence of sweating at low physical loads, usually characterizes the stress of adaptive mechanisms [10]. Certainly, these signs are significant with frequent registration.

\section{Conclusion}

Subjective features can be used to verify the regulatory features of the cardiovascular system, which are associated with the centralization of effects (for the majority of signs). However, their intertype individual differentiation is difficult. On the other hand, the autonomy of influences can be determined as a manifestation of optimal regulatory support (Type III) only in the absence of most subjective features, and not always. An even bigger problem is the definition of Type IV, which is differentiated from Type III, only on the basis of sweating at rest $(27.3 \%$ vs. $8 \%)$, which is not a clear subjective feature, although it can help distinguish between states of high fitness and overexertion according to parasympathetic type.

So, taking into account the types of heart rate regulation, the questionnaire can be helpful in determining the condition of the athlete. It is most likely that it can be effective in differentiating states of overstrain by parasympathetic type and state of high fitness.

Conflicts of interest: authors have no conflict of interest to declare. Конфлікт інтересів: відсутній.

Information about the authors:

Guzii O. V., PhD, Associate Professor of the Department of Sports Medicine and Human Health, Lviv State University of Physical Culture named after Ivan Boberskyj, Ukraine.

ORCID ID: 0000-0001-5420-8526

Mahlovanyi A. V., Dr. hab., Professor, Honored Professor of Danylo Halytsky Lviv National Medical University, Vice-Rector for Scientific and Pedagogical Work, Danylo Halytsky Lviv National Medical University, Ukraine.

ORCID ID: 0000-0002-1792-597X

Trach V. M., PhD, Professor of the Department of Biochemistry and Hygiene, Lviv State University of Physical Culture named after Ivan Boberskyj, Ukraine.

ORCID ID: $\underline{0000-0002-2506-1710}$
Відомості про авторів:

Гузій О. В., канд. наук із фрізичного виховання та спорту, доцент каф. спортивної медицини, здоров'я людини, Львівський державний університет фрізичної культури імені Івана Боберського, Україна. Магльований А. В., д-р біол. наук, професор, заслужений професор Львівського національного медичного університету імені Данила Галицького, проректор із науково-педагогічної роботи, Львівський національний медичний університет імені Данила Галицького, Україна. Трач В. М., канд. біол. наук, професор каф. біохімії і гігієни, Львівський державний університет фізичної культури імені Івана Боберського, Україна.

Сведения об авторах:

Гузий О. В., канд. наук по физическому воспитанию и спорту, доцент каф. спортивной медицины, здоровья человека, Львовский государственный университет физической культуры имени Ивана Боберского, Украина.

Маглёваный А. В., д-р биол. наук, профессор, заслуженный профессор Львовского национального медицинского университета имени Данила Галицкого, проректор по научно-педагогической работе, Львовский национальный медицинский университет имени Данила Галицкого, Украина.

Трач В. М., канд. биол. наук, профессор каф. биохимии и гигиены, Львовский государственный университет физической культуры имени Ивана Боберского, Украина.

\section{References}

[1] Bourdon, P. C., Cardinale, M., Murray, A., Gastin, P., Kellmann, M., Varley, M. C., Gabbett, T. J., Coutts, A. J., Burgess, D. J., Gregson, W., \& Cable, N. T. (2017). Monitoring Athlete Training Loads: Consensus Statement. International journal of sports physiology and performance, 12(Suppl 2), S2161-S2170. https://doi.org/10.1123/IJSPP.2017-0208

[2] Meeusen, R., Duclos, M., Foster, C., Fry, A., Gleeson, M., Nieman, D., Raglin, J., Rietjens, G., Steinacker, J., Urhausen, A., European College of Sport Science, \& American College of Sports Medicine (2013). Prevention, diagnosis, and treatment of the overtraining syndrome: joint consensus statement of the European College of Sport Science and the American College of Sports Medicine. Medicine and science in sports and exercise, 45(1), 186-205. https://doi.org/10.1249/ MSS.0b013e318279a10a

[3] Halson S. L. (2014). Monitoring training load to understand fatigue in athletes. Sports medicine, 44(Suppl 2), S139-S147. https://doi. org/10.1007/s40279-014-0253-z

[4] Romanchuk, A. P. (2003). Kontseptual'nye predposylki sanogeneticheskogo monitoringa lits, zanimayushchikhsya fizicheskoi kul'turoi i sportom [Conceptual preconditions of sanogenetical monitoring of persons engaged in physical culture and sports]. Theory and Practice of Physical Culture, (1), 50-53. [in Russian].

[5] Romanchuk, A. P. (2002). Kompleksnaya otsenka mezhsistemnykh otnoshenii funktsional'nykh reaktsii organizma na fizicheskuyu nagruzku [Complex estimation of intersystem relations of functional reactions on physical load]. Theory and Practice of Physical Culture, (4), 51-54. [in Russian].

[6] Heidari, J., Kölling, S., Pelka, M., \& Kellmann, M. (2018). Monitoring the recovery-stress state in athletes. Abingdon, Routle: Sport, Recovery and Performance: Interdisciplinary Insights.

[7] Scherr, J., Wolfarth, B., Christle, J. W., Pressler, A., Wagenpfeil, S., \& Halle, M. (2013). Associations between Borg's rating of perceived exertion and physiological measures of exercise intensity. European journal of applied physiology, 113(1), 147-155. https://doi.org/10.1007/ s00421-012-2421-x

[8] Bresciani, G., Cuevas, M. J., Molinero, O., Almar, M., Suay, F., Salvador, A., de Paz, J. A., Marquez, S., \& González-Gallego, J. (2011). Signs of overload after an intensified training. International journal of sports medicine, 32(5), 338-343. https://doi. org/10.1055/s-0031-1271764

[9] Decroix, L., Lamberts, R. P., \& Meeusen, R. (2018). Can the Lamberts and Lambert Submaximal Cycle Test Reflect Overreaching in Professional Cyclists?. International journal of sports physiology and performance, 13(1), 23-28. https://doi.org/10.1123/ijspp.2016-0685

[10] Buchheit, M., Racinais, S., Bilsborough, J. C., Bourdon, P. C., Voss, S. C., Hocking, J., Cordy, J., Mendez-Villanueva, A., \& Coutts, A. J. (2013). Monitoring fitness, fatigue and running performance during a 
pre-season training camp in elite football players. Journal of science and medicine in sport, 16(6), 550-555. https://doi.org/10.1016/j. jsams.2012.12.003

[11] Pankova, N. B., Bogdanova, E. V., Karganov, M. Yu., Eigel, M. Ya., Kuznetsov, P. P., \& Simakov, O. V. (2013). Poslenagruzochnaya dinamika pokazatelei serdechno-sosudistoi sistemy u yunykh sportsmenov (rezul'taty spiro-arterio-kardioritmografii). [After-load dynamics ofcardiovascular system inyoung athletes (results usedwith method of spyroarteriocardiorithmography)]. Valeologiya -Valeology, (3), 54-60. [in Russian].

[12] Bellenger, C. R., Fuller, J. T., Thomson, R. L., Davison, K., Robertson, E. Y., \& Buckley, J. D. (2016). Monitoring Athletic Training Status Through Autonomic Heart Rate Regulation: A Systematic Review and Meta-Analysis. Sports medicine, 46(10), 1461-1486. https://doi. org/10.1007/s40279-016-0484-2

[13] Guzii, O. V., \& Romanchuk, A. P. (2016). Chutlyvist arterialnoho barorefleksu pry vidnovlenni orhanizmu pislia trenuvalnoho navantazhennia [Sensitivity of arterial baroreflex in the terms of body recovery after training load]. Zaporozhye medical journal, (3), 24-29. [in Ukrainian]. https://doi.org/10.14739/2310-1210.2016.3.76922

[14] Guzii, O. V., \& Romanchuk, A. P. (2017). Heart rate variability during controlled respiration after endurance training. Journal of Physical Education and Sport, 17(3), 2024-2029. https://doi.org/10.7752/ ipes.2017.03203

[15] Romanchuk, O. P.,\& Guzii, O. V. (2020). Peculiarities of Changes in Respiratory Variability under the Influence of Training Load in Athletes with Cardiovascular Overstrain by Sympathetic Type. International Journal of Education and Science, 3(2), 54. https://doi.org/10.26697/ijes.2020.2.38

[16] Romanchuk, A., \& Guzii, O. (2020). Variability and Pattern of Spontaneous Respiration in Different Types of Cardiac Rhythm Regulation of Highly Trained Athletes. International Journal of Human Movement and Sports Sciences, 8(6), 483-493. https://doi.org/10.13189/ saj.2020.080622

[17] Guzii, O. V., Romanchuk, A. P., \& Mahlovanyy, A. V.(2020). Sensomotorni pokaznyky yak kryterii vplyvu intensyvnykh fizychnykh navantazhen na orhanizm sportsmena [Sensorimotor Indicators as Criteria of the Intense Physical Loads Influence on the Athlete's Body]. Ukrainskyi zhurnal medytsyny, biolohii ta sportu, 5(3), 351-358. [in Ukrainian]

[18] Romanchuk, O. P., \& Guzii, O. V. (2020). Sensorimotor Criteria for the Formation of the Autonomic Overstrain of the Athletes' Cardiovascular System. International Journal of Science Annals, 3(1), 46-53. https:// doi.org/10.26697/iisa.2020.1.6

[19] Semashko, L. V., Pankova, N. B., \& Karganov, M. Y. (2010). Izmeneniya psikhofiziologicheskikh pokazatelei i funktsional'nogo sostoyaniya kardio-respiratornoi sistemy u detei i podrostkov, zanimayushchikhsya po "metodike psikhofiziologicheskoi adaptatsii k vysokim psikhoemotsional'nym i fizicheskim nagruzkam" [Changes in psychophysiological parameters and functional state of the cardiorespiratory system in children and adolescents engaged in the "method of psychophysiological adaptation to high psycho-emotional and physical stress"]. Bulletin of Rehabilitation Medicine, (2), 41-45. [in Russian].

[20] Gleeson, M. (2002). Biochemical and immunological markers of over-training. Journal of sports science \& medicine, 1(2), 31-41.

[21] Wiewelhove, T., Raeder, C., Meyer, T., Kellmann, M., Pfeiffer, M., \& Ferrauti, A. (2016). Effect of Repeated Active Recovery During a High-Intensity Interval-Training Shock Microcycle on Markers of Fatigue. International journal of sports physiology and performance, 11(8), 1060-1066. https://doi.org/10.1123/iispp.2015-0494

[22] Romanchuk, A. P. (2002). Rezul'taty primeneniya metoda lazernoi korrelyatsionnoi spektroskopii v sporte [Results of applying the method of laser correlation spectroscopy in sports]. Theory and Practice of Physical Culture, (1), 35-37. [in Russian].

[23] Goldstein, D. S. (2009). Sympathetic noradrenergic and adrenomedullary hormonal systems in stress and distress. In Encyclopedia of Neuroscience (pp. 673-678). Elsevier Ltd. https://doi.org/10.1016/ B978-008045046-9.00098-X

[24] Grove, J. R., Main, L. C., Partridge, K., Bishop, D. J., Russell, S., Shepherdson, A., \& Ferguson, L. (2014). Training distress and performance readiness: laboratory and field validation of a brief self-report measure. Scandinavian journal of medicine \& science in sports, 24(6), e483-e490. https://doi.org/10.1111/sms.12214

[25] Mittly, V., Németh, Z., Berényi, K., \& Mintál, T.(2016). Mind Does Matter: The Psychological Effect of Ankle Injury in Sport. Journal of Psychology \& Psychotherapy, 6(4), 1000278. https://doi. org/10.4172/2161-0487.1000278
[26] Freitas, V. H., Nakamura, F. Y., Miloski, B., Samulski, D., \& Bara-Filho, M. G. (2014). Sensitivity of physiological and psychological markers to training load intensification in volleyball players. Journal of sports science \& medicine, 13(3), 571-579.

[27] Saw, A. E., Main, L. C., \& Gastin, P. B. (2015). Role of a self-report measure in athlete preparation. Journal of strength and conditioning research, 29(3), 685-691. https://doi.org/10.1519/ JSC.0000000000000698

[28] Kallus, K. W. (2016). Stress and Recovery:An Overview. In K. W. Kallus \& M. Kellmann (Eds.). The Recovery-Stress Questionnaires: User Manual. Frankfurt am Main: Pearson Assessment \& Information $\mathrm{GmbH}$.

[29] Brink, M. S., Visscher, C., Coutts, A. J., \& Lemmink, K. A. (2012). Changes in perceived stress and recovery in overreached young elite soccer players. Scandinavian journal of medicine \& science in sports, 22(2), 285-292. https://doi.org/10.1111/j.1600-0838.2010.01237.x

[30] Laux, P., Krumm, B., Diers, M., \& Flor, H. (2015). Recovery-stress balance and injury risk in professional football players: a prospective study. Journal of sports sciences, 33(20), 2140-2148. https://doi.org /10.1080/02640414.2015.1064538

[31] Meister, S., Faude, O., Ammann, T., Schnittker, R., \& Meyer, T. (2013). Indicators for high physical strain and overload in elite football players. Scandinavian journal of medicine \& science in sports, 23(2), 156-163. https://doi.org/10.1111/j.1600-0838.2011.01354.x

[32] van der Does, H. T., Brink, M. S., Otter, R. T., Visscher, C., \& Lemmink, K. A. (2017). Injury Risk Is Increased by Changes in Perceived Recovery of Team Sport Players. Clinical journal of sport medicine, 27(1), 46-51. https://doi.org/10.1097/JSM.0000000000000306

[33] Kölling, S., Steinacker, J. M., Endler, S., Ferrauti, A., Meyer, T., \& Kellmann, M. (2016). The longer the better: Sleep-wake patterns during preparation of the World Rowing Junior Championships. Chronobiology international, 33(1), 73-84. https://doi.org/10.3109/0 7420528.2015.1118384

[34] Fullagar, H. H., Duffield, R., Skorski, S., White, D., Bloomfield, J., Kölling, S., \& Meyer, T. (2016). Sleep, Travel, and Recovery Responses of National Footballers During and After Long-Haul International Air Travel. International journal of sports physiology and performance, 11(1), 86-95. https://doi.org/10.1123/ijspp.2015-0012

[35] Nässi, A., Ferrauti, A., Meyer, T., Pfeiffer, M., \& Kellmann, M. (2017). Development of two short measures for recovery and stress in sport. European journal of sport science, 17(7), 894-903. https://doi.org/10 $.1080 / 17461391.2017 .1318180$

[36] Korman, N., Armour, M., Chapman, J., Rosenbaum, S., Kisely, S., Suetani, S., Firth, J., \& Siskind, D. (2020). High Intensity Interval training (HIIT) for people with severe mental illness: A systematic review \& meta-analysis of intervention studies- considering diverse approaches for mental and physical recovery. Psychiatry research, 284, 112601. https://doi.org/10.1016/j.psychres.2019.112601

[37] Impellizzeri, F. M., Rampinini, E., Coutts, A. J., Sassi, A., \& Marcora S. M. (2004). Use of RPE-based training load in soccer. Medicine and science in sports and exercise, 36(6), 1042-1047. https://doi. org/10.1249/01.mss.0000128199.23901.2f

[38] Pivovarov, V. V. (2006). Spiroarteriokardioritmograf [Spiroarteriocardiorytmograph]. Meditsinskaya tekhnika, (1), 38-41. [in Russian].

[39] Guzii, O. V., Romanchuk, A. P., Mahlovanyi, A. V., \& Trach, V. M. (2019). Polyfunctional express-evaluation criteria of the sportsman organism state. Journal of Physical Education and Sport, 19(4), 23522358. https://doi.org/10.7752/jpes.2019.04356

[40] Guzii, O., \& Romanchuk, A. (2017). Differentiation of Hemodynamics of Top Athletes Depending on Heart Rate Variability after Training. Journal of Advances in Medicine and Medical Research, 22(3), 1-10. https://doi.org/10.9734/JAMMR/2017/33619

[41] Romanchuk, A. P. (2005). Vegetativnaya regulyatsiya kardiorespiratornoi sistemy $v$ dinamike godichnogo trenirovochnogo tsikla [Features of autonomic regulation of cardiorespiration system in dynamics of training cycle of year]. Theory and practice of physical culture, (6), 42-45. [in Russian].

[42] Romanchuk, O. P. (2010). Likarsko-pedahohichnyi kontrol v ozdorovchii fizychnii kulturi [Medical and pedagogical control in health-improving physical culture]. Odesa, Ukrainian: Bukaev V. V. [in Ukrainian].

[43] Shlyk, N. I. (2016). Upravlenie trenirovochnym protsessom sportsmenov s uchetom individual'nykh kharakteristik variabel'nosti ritma serdtsa. Fiziologiya cheloveka [Management of athletic training taking into account individual heart rate variability characteristics]. Fiziologiya cheloveka, 42(6), 81-91. [in Russian]. https://doi.org/10.7868/ $\underline{\mathrm{S} 0131164616060187}$ 
[44] Shlyk, N. I. (2020). Variabel'nost' serdechnogo ritma v pokoe i ortostaze pri raznykh diapazonakh znachenii MxDMn u lyzhnits-gonshchits $v$ trenirovochnom protsesse [Heart rate variability at rest and during an orthostatic challenge at different ranges of MxDMn values in female skiers in the training process]. Nauka i sport: sovremennye tendentsii, 1(8), 83-96. [in Russian].

[45] Guzii, O.V., Romanchuk, A.P., \& Maglovanyy, A.V. (2020). Postnavantazhuvalna dynamika pokaznykiv variabelnosti sertsevoho rytmu u vysokokvalifikovanykh sportsmeniv pry formuvanni perenapruzhen za sympatychnym ta parasympatychnym typamy [Post-Loading Dynamics of Heart Rate Variability Indices in Highly Qualified Athletes in the Formation of Overstrains by Sympathetic and Parasympathetic Types]. Art of Medicine, (4), 28-36. [in Ukrainian]. https://doi.org/10.21802/ artm.2020.4.16.28

[46] Drezner, J. A., Sharma, S., Baggish, A., Papadakis, M., Wilson, M. G., Prutkin, J. M., Gerche, A., Ackerman, M. J., Borjesson, M., Salerno, J. C., Asif, I. M., Owens, D. S., Chung, E. H., Emery, M. S., Froelicher, V. F., Heidbuchel, H., Adamuz, C., Asplund, C. A., Cohen, G., Harmon, K. G., ... Corrado, D. (2017). International criteria for electrocardiographic interpretation in athletes: Consensus statement. British journal of sports medicine, 51(9), 704-731. https://doi.org/10.1136/ bjsports-2016-097331

[47] Mykhaliuk, Ye. L., \& Syvolap, V. V. (2019). Osoblyvosti elektrokardiohramy osib, yaki zaimaiutsia sportom. Povidomlennia I (ohliad literatury) [Electrocardiographic features in people involved in sports. Report I (a literature review)]. Zaporozhye medical journal, 21(2), 264-269. [in Ukrainian]. https://doi.org/10.14739/23101210.2019.2.161513

[48] Mykhaliuk, Ye. L., Syvolap, V. V., Hunina, L. M., \& Holovashchenko, R. V. (2019). Fiziolohichni ta potentsiino patolohichni zminy na EKH u predstavnykiv plavannia riznykh sportyvnykh kvalifikatsii [Physiological and potentially pathological ECG changes in swimmers of different sports qualifications]. Zaporozhye medical journal, 21(1), 39-43. [in Ukrainian]. https://doi.org/10.14739/2310-1210.2019.1.155800

[49] Mykhaliuk, Ye. L., Hunina, L. M., \& Kuzmenko, M. V. (2018). Analiz elektrokardiohrafichnykh pokaznykiv u yedynobortsiv zalezhno vid sportyvnoi kvalifikatsii [Analysis of Electrocardiographic Indicators in Combating Sportsmen Depending on their Sports Qualification]. Ukrainskyi zhurnal medytsyny, biolohii ta sportu, 3(3), 176-183. [in Ukrainian].

[50] Flatt, A. A., Esco, M. R., Allen, J. R., Robinson, J. B., Earley, R. L., Fedewa, M. V., Bragg, A., Keith, C. M., \& Wingo, J. E. (2018). Heart Rate Variability and Training Load Among National Collegiate Athletic Association Division 1 College Football Players Throughout Spring Camp. Journal of strength and conditioning research, 32(11), 31273134. https://doi.org/10.1519/JSC.0000000000002241

[51] Flatt, A. A., Hornikel, B., \& Esco, M. R. (2017). Heart rate variability and psychometric responses to overload and tapering in collegiate sprint-swimmers. Journal of science and medicine in sport, 20(6), 606-610. https://doi.org/10.1016/j.jsams.2016.10.017

[52] Nuuttila, O. P., Nikander, A., Polomoshnov, D., Laukkanen, J. A., \& Häkkinen, K. (2017). Effects of HRV-Guided vs. Predetermined Block Training on Performance, HRV and Serum Hormones. International journal of sports medicine, 38(12), 909-920. https://doi. org/10.1055/s-0043-115122

[53] Pelliccia, A., Maron, B. J., Culasso, F., Di Paolo, F. M., Spataro, A., Biffi, A., Caselli, G., \& Piovano, P. (2000). Clinical significance of abnormal electrocardiographic patterns in trained athletes. Circulation, 102(3), 278-284. https://doi.org/10.1161/01.cir.102.3.278

[54] Walsh, N. P., Halson, S. L., Sargent, C., Roach, G. D., Nédélec, M., Gupta, L., Leeder, J., Fullagar, H. H., Coutts, A. J., Edwards, B. J., Pullinger, S. A., Robertson, C. M., Burniston, J. G., Lastella, M., Le Meur, Y., Hausswirth, C., Bender, A. M., Grandner, M. A., \& Samuels, C. H. (2020). Sleep and the athlete: narrative review and 2021 expert consensus recommendations. British journal of sports medicine, bjsports-2020-102025. Advance online publication. https:// doi.org/10.1136/bjsports-2020-102025 